\title{
Somatotroph Hyperplasia
}

\author{
SUCCESSFUL TREATMENT OF ACROMEGALY
}

\section{BY REMOVAL OF A PANCREATIC ISLET TUMOR SECRETING \\ A GROWTH HORMONE-RELEASING FACTOR}

\author{
M. O. Thorner, R. L. Perryman, M. J. Cronin, A. D. Rogol, M. Draznin, \\ A. Johanson, W. Vale, E. Horvath, and K. Kovacs, Departments of \\ Internal Medicine, Physiology, Pharmacology, and Pediatrics, University of \\ Virginia Medical Center, Charlottesville, Virginia 22908; Salk Institute, San \\ Diego, California 92138; Department of Pathology, St. Michael's Hospital, \\ University of Toronto, Ontario, Canada
}

A B S T R A C T A 21-yr-old woman with Turner's syndrome presented with signs and symptoms of acromegaly. The serum growth hormone (GH) $(95 \pm 9.4 \mathrm{ng} /$ $\mathrm{ml}$; mean $\pm \mathrm{SEM})$ and somatomedin $\mathrm{C}(11 \mathrm{U} / \mathrm{ml})$ levels were elevated, and an increase in GH levels after glucose instead of normal suppression, increase after thyrotropin-releasing hormone (TRH) administration instead of no change, and decrease after dopamine administration instead of stimulation were observed. The pituitary fossa volume was greater than normal $(1,440$ $\mathrm{mm}^{3}$ ) and the presence of a pituitary tumor was assumed. After tissue removal at transsphenoidal surgery, histological study revealed somatotroph hyperplasia rather than a discrete adenoma. Postoperatively, she remained clinically acromegalic and continued to show increased GH and somatomedin levels. A search was made for ectopic source of a growth hormonereleasing factor (GRF). Computer tomographic scan revealed a $5-\mathrm{cm}$ Diam tumor in the tail of the pancreas. Following removal of this tumor, serum $\mathrm{GH}$ fell from 70 to $3 \mathrm{ng} / \mathrm{ml}$ over $2 \mathrm{~h}$, and remained low for the subsequent $5 \mathrm{mo}$. Serum somatomedin $\mathrm{C}$ levels fell from 7.2 to normal by $6 \mathrm{wk}$ postoperatively. There were no longer paradoxical GH responses to glucose, TRH, and dopamine. Both the medium that held the tumor cells at surgery and extracts of the tumor contained a peptide with GRF activity. The GRF contained in the tumor extract coeluted on Sephadex

Dr. Perryman's present address is 1722 Pine Street, Suite 307, Montgomery, AL 36106; Dr. Draznin's present address is VA Hospital, Palo Alto, CA 94305.

Received for publication 31 March 1982 and in revised form 28 June 1982.
G-50 chromatography with rat hypothalamic GHreleasing activity. Stimulation of $\mathrm{GH}$ from rat somatotrophs in vitro was achieved at the nanomolar range, using the tumor extract.

The patient's course demonstrates the importance of careful interpretation of pituitary histology. Elevated serum $\mathrm{GH}$ and somatomedin $\mathrm{C}$ levels in a patient with an enlarged sella turcica and the characteristic responses seen in acromegaly to $\mathrm{TRH}$, dopamine, and glucose do not occur exclusively in patients with discrete pituitary tumors and acromegaly. This condition can also occur with somatotroph hyperplasia and then revert to normal after removal of the GRF source. Thus, in patients with acromegaly a consideration of ectopic GRF secretion should be made, and therefore, careful pituitary histology is mandatory. Consideration for chest and abdominal computer tomographic scans before pituitary surgery, in spite of their low yield, may be justified.

\section{INTRODUCTION}

Acromegaly is usually associated with a pituitary tumor. Only nine previous cases of acromegaly associated with ectopic growth hormone-releasing factor $(G R F)^{1}$ secretion have been reported (1-10). These patients have presented, with one exception (7), either with the mass effects of their extrapituitary tumors or

\footnotetext{
${ }^{1}$ Abbreviations used in this paper: CT scan, computer tomographic scan; FSH, follicle-stimulating hormone; $\mathbf{G H}$, growth hormone; GRF, growth hormone-releasing factor; LH, luteinizing hormone; OGTT, oral glucose tolerance test; RER, rough-surfaced endoplasmic reticulum; TRH, thyrotropin-releasing hormone; TSH, thyrotropin.
} 
with metastases, and the diagnoses have been made in retrospect or even at postmortem examination $(2$, $3,8,9)$.

We now report a young woman with Turner's syndrome and acromegaly. At transsphenoidal surgery an apparent pituitary tumor was removed. Histological examination, however, revealed somatotroph hyperplasia. Postoperatively the patient remained acromegalic. In a systematic search for an ectopic source of a GRF, a computer tomographic (CT) scan of the abdomen revealed a tumor in the tail of the pancreas. After successful removal of the tumor, the acromegalic syndrome resolved. The dynamics of growth hormone (GH) and prolactin secretion in this patient and characterization of the pancreatic tumor and the GRF are described.

\section{METHODS}

\section{Case report}

This 21-yr-old White woman was found to have Turner's syndrome at age $11 \mathrm{yr}$ when she underwent correction of coarctation of the aorta and patent ductus arteriosus. Physical examination at that time revealed short stature (height age, $7 \mathrm{yr}$ ), mild webbing of the neck, a low posterior hairline, short broad hands with small hyperconvex fingernails, widely spaced nipples, an increased carrying angle at the elbow, and multiple pigmented cutaneous nevi. Bone age was 9 yr. Chromosomal karyotpye was $45 \mathrm{XO}$. Endocrine evaluation included the following: normal oral glucose tolerance; serum thyroxine $\left(\mathrm{T}_{4}\right) 6.2 \mu \mathrm{g} / \mathrm{dl}$ (normal 5.2-11.8); serum luteinizing hormone $(\mathrm{LH}) 25 \mathrm{mIU} / \mathrm{ml}$ (normal for prepubertal child $<5$ ); serum follicle-stimulating hormone (FSH) $138 \mathrm{mIU} / \mathrm{ml}$ (mean of five samples; normal for prepubertal child $<5$ ) and serum $\mathrm{GH} 0.9 \mathrm{ng} / \mathrm{ml}$. To stimulate linear growth, she was treated with oxandrolone, $0.1 \mathrm{mg} /$ $\mathrm{kg}$ per d. After $1 \mathrm{yr}$ of anabolic steroid therapy, she was noted to have mild thyromegaly and symptoms of hypothyroidism. Serum thyrotrophin (TSH) was elevated at $14 \mu \mathrm{U} /$ $\mathrm{ml}($ normal $<10)$ and antithyroid antibodies were present as measured by an indirect immunofluorescent technique. Thyroid extract, 2 grains daily, was started. Linear growth progressed adequately on oxandrolone and thyroid hormone therapy. After $3 \mathrm{yr}$, conjugated estrogens (Premarin, 1.25 mg daily) were begun. After 2 mo she noted her first menstrual bleeding. She then received estrogens for $3 \mathrm{wk}$ of each month and withdrawal bleeding was noted each time the estrogen was stopped. She continued to receive the combination of conjugated estrogens and oxandrolone for $18 \mathrm{mo}$. At that time oxandrolone was discontinued and a combination estrogen-progestin preparation (Ortho-Novum 1/80; norethindrone, $1 \mathrm{mg}$ and mestranol, $80 \mu \mathrm{g}$ daily for 21 of $28 \mathrm{~d}$ ) was substituted for the conjugated estrogens. For 2.5 $\mathrm{yr}$ she had regular withdrawal bleeding.

At age 20 yr the patient presented with a 2-mo history of amenorrhea despite continuation of the cyclic estrogen-progestin therapy. A history of galactorrhea, initially noted 2 yr previously, increasing hand size and foot width, and an increasing number of skin tags was elicited. Physical examination revealed the characteristic features of Turner's syndrome described above as well as galactorrhea expressible bilaterally. Her height was $146 \mathrm{~cm}$ and her weight $56 \mathrm{~kg}$. Endocrine evaluation while receiving Ortho-Novum 1/80 and desiccated thyroid 2 grains daily showed serum prolactin $66 \mathrm{ng} / \mathrm{ml}$ (normal <20); serum somatomedin-C $7.2 \mathrm{U} / \mathrm{ml}$ (normal <2); serum LH $5.4 \mathrm{mIU} / \mathrm{ml}$; serum FSH $3.5 \mathrm{mIU} /$ $\mathrm{ml}$; and serum TSH $3.6 \mu \mathrm{U} / \mathrm{ml}$.

Polytomography of the pituitary fossa showed downward extension of the fossa with a posterior tilt of the dorsum sellae indicating expansion of the pituitary fossa. The calculated volume of the sella, according to the method of $\mathrm{Di}$ Chiro and Nelson (11), was $1,440 \mathrm{~mm}^{3}$ (normal range, 2421,042). Head CT scan, after intravenous contrast medium, demonstrated enhancement in the sella and suprasellar regions suggesting a small suprasellar extension of the pituitary gland.

Endocrine evaluation before pituitary microsurgery confirmed acromegaly by elevated serum somatomedin $\mathrm{C}$ and GH concentrations. Basal serum prolactin levels were elevated $(88 \pm 3 \mathrm{ng} / \mathrm{ml} ; n=10$, mean \pm SEM). Basal serum $\mathrm{GH}$ levels through the day were elevated $(95 \pm 9.4 \mathrm{ng} / \mathrm{ml}$; $n=10$, mean \pm SEM) and the GH concentrations increased paradoxically after oral glucose (Table I).

The patient underwent transsphenoidal surgery and a large "tumor" was identified and removed. The patient made an uneventful recovery, but serum GH and somatomedin $C$ levels remained elevated (Table I). She was, therefore, treated with bromocriptine $2.5 \mathrm{mg}$ q.i.d. without clinical or hormonal improvement other than suppression of serum prolactin. Pituitary histology, as described in more detail below, showed somatotroph hyperplasia. Bromocriptine therapy was discontinued and the patient was studied again 2 wk later.

A search was made for an ectopic source of GRF. Urinary excretion rates of catecholamines (norepinephrine $29 \mu \mathrm{g} / 24$ h [normal <80]; epinephrine nondetectable, and 5-hydroxyindole acetic acid $5 \mathrm{mg} / 24 \mathrm{~h}$ [normal $<10$ ] were within normal limits. A CT scan of the abdomen showed a $5-\mathrm{cm}$ Diam mass with capsular calcification in the tail of the pancreas, which was enhanced by intravenous injection of contrast material (Renograffin 60). There was no evidence for metastatic lesions.

At laparotomy a 55-g tumor was excised from the tail of the pancreas. There was no evidence for tumor extension or for metastases. The patient recovered postoperatively with resolution of acromegaly by both clinical and biochemical criteria (Table I).

\section{Hormonal analysis}

Human serum LH, FSH, and GH were measured by radioimmunoassay (RIA) using reagents kindly supplied by the Pituitary Hormone Distribution Program, National Institute of Arthritis, Diabetes, Digestive and Kidney Diseases (NIADDKD) (12). Serum prolactin, and other circulating hormones were also measured by RIA using reagents purchased from commercial sources (12). Serum somatomedin $\mathrm{C}$ was determined by the Nichols Institute (San Pedro, CA) using the method of Furlanetto et al. (13).

Rat prolactin and $\mathrm{GH}$ were measured in the media from primary cultures of anterior pituitary cells by RIA using reagents kindly supplied by the Pituitary Hormone Distribution Program, NIADDKD. Rat prolactin and GH reference preparations RP-2 and RP-1, respectively, were used as standards. The intraassay variation was $3 \%$ for rat prolactin at $17 \mathrm{ng} / \mathrm{ml}$ and $3.5 \%$ for rat $\mathrm{GH}$ at $110 \mathrm{ng} / \mathrm{ml}$.

\section{Clinical studies}

The clinical studies were performed at the Clinical Research Center of the University of Virginia and written informed consent was obtained. 
TABLE I

Blood Glucose and Serum GH during OGTT, Mean Serum GH throughout the Day, and Somatomedin Levels before and after Pituitary Microsurgery (TSS), during Bromocriptine Therapy, and after Removal of a GRF-secreting Pancreatic Tumor

\begin{tabular}{|c|c|c|c|c|c|c|}
\hline & \multirow[b]{2}{*}{$\begin{array}{l}\text { Before } \\
\text { TSS }\end{array}$} & \multirow[b]{2}{*}{$\begin{array}{c}7 \text { wks } \\
\text { after TSS }\end{array}$} & \multirow{2}{*}{$\begin{array}{c}17 \text { wk of } \\
\text { bromocriptine } 2.5 \mathrm{mg} \\
\text { q.i.d. }\end{array}$} & \multicolumn{3}{|c|}{$\begin{array}{l}\text { After removal of GRF-secreting } \\
\text { pancreatic tumor }\end{array}$} \\
\hline & & & & 1 wk & $6 \mathrm{wk}$ & $17 \mathrm{wk}$ \\
\hline \multicolumn{7}{|l|}{$\begin{array}{l}\text { OGTT. Blood glucose, } m g / d l \\
\text { Time, } \min \end{array}$} \\
\hline-30 & 52 & 105 & 90 & 79 & 68 & 84 \\
\hline 0 & 67 & 103 & 81 & 78 & 69 & 80 \\
\hline 30 & 79 & 138 & 127 & 169 & 174 & 134 \\
\hline 60 & 136 & 167 & 119 & 200 & 255 & 152 \\
\hline 90 & 142 & 157 & 153 & 130 & 188 & 132 \\
\hline 120 & 156 & 128 & 155 & 108 & 109 & 155 \\
\hline \multicolumn{7}{|l|}{ Serum GH, $n g / m l$} \\
\hline-30 & 86 & 28 & 55 & 5 & 6 & 9 \\
\hline 0 & 111 & 34 & 59 & 5 & 7 & 8 \\
\hline 30 & 145 & - & 49 & 5 & 8 & 5 \\
\hline 60 & 148 & 69 & 81 & 9 & 6 & 5 \\
\hline 90 & 194 & 61 & 88 & 7 & 7 & 8 \\
\hline 120 & 323 & 67 & 80 & 7 & 5 & 9 \\
\hline Serum $\mathrm{GH}^{\bullet}, n g / m l$ & $95 \pm 9.4$ & $52 \pm 6.2$ & $71 \pm 8.4$ & - & $4 \pm 0.3$ & $6 \pm 0.8$ \\
\hline Serum somatomedin $C, U / m l$ & 11 & 7.7 & 8.6 & - & 1.2 & 0.7 \\
\hline
\end{tabular}

- Represent concentrations (mean $\pm \mathrm{SEM} ; \mathrm{n}=10$ ) throughout the day.

The thyrotropin-releasing hormone (TRH) and the oral glucose tolerance tests (OGTT), and dopamine infusions were each carried out following an overnight fast with only water ad lib. $1 \mathrm{~h}$ before the commencement of each test a forearm venous cannula (heparin-lock) was placed for the TRH and OGT tests. The patient remained fasting throughout the studies.

The TRH test was performed by withdrawing blood samples through the heparin-lock cannula at $-30,-15,0,20$, and $60 \mathrm{~min}$ for determination of serum $\mathrm{GH}, \mathrm{TSH}$, and prolactin. TRH (Relefact, Hoechst-Roussel Pharmaceuticals Inc., Somerville, NJ), $500 \mu \mathrm{g}$, was given intravenously as a bolus through the cannula immediately after the 0 -min blood sample was withdrawn.

The OGTT was performed by withdrawing blood samples for determination of blood glucose and serum $\mathrm{GH}$ at -30 , $0,30,60,90$, and $120 \mathrm{~min}$. $100 \mathrm{~g}$ glucose was given by mouth immediately after the 0 -min blood sample.

Control and dopamine infusions were performed on consecutive days. At $0700 \mathrm{~h}$ a heparin-lock cannula was inserted into an antecubital vein in each arm. One was used for the infusion and the other for sampling. Blood samples were drawn every $30 \mathrm{~min}$ from 0800 to $1800 \mathrm{~h}$ for determination of serum GH and prolactin concentrations. During the control study 5\% dextrose in water was infused using a Harvard infusion pump (Harvard Apparatus Co., Inc., S. Natick, MA) at $0.9 \mathrm{ml} / \mathrm{min}$ for $8 \mathrm{~h}$ from 0800 to $1600 \mathrm{~h}$. On the following day $5 \%$ dextrose was infused for $4 \mathrm{~h}$ from 0800 to $1200 \mathrm{~h}$ and dopamine (Intropin, Anar-Stone Laboratories, Inc., Mount Prospect, IL) at $4 \mu \mathrm{g} / \mathrm{kg}$ per min from 1200 to $1600 \mathrm{~h}$.

\section{Pathological studies}

For light microscopy, pituitary tissue and the pancreatic tumor were fixed in buffered formalin and embedded in paraffin. Sections, 4-6- $\mu \mathrm{m}$ thick were stained with hematoxylin-eosin, hematoxylin-phloxin-saffron, periodic acidSchiff (PAS), and lead hematoxylin. The Gordon-Sweet silver technique was used to study reticulin fibers in the pituitary and the Grimelius method for the demonstration of argyrophil granules in the pancreatic tumor. The immunoperoxidase technique, as described elsewhere (14), was used to detect $\mathrm{GH}$, prolactin, FSH, and LH in the pituitary tissue, and insulin, glucagon, somatostatin, gastrin, calcitonin, ACTH $_{1-39}, \mathrm{GH}$, prolactin, and neuron-specific enolase in the pancreatic tumor. For electron microscopy, small pieces of tissue from the pituitary and pancreatic tumor, respectively, were fixed in glutaraldehyde, postfixed with osmium tetroxide, dehydrated in graded concentrations of ethanol, and embedded in epoxy resin. Ultrathin sections were stained with uranyl acetate and lead citrate.

\section{Bioassays for GRF activity}

Rat anterior pituitary primary culture. This was performed by a modification (15) of the method described by Vale et al. (16). The dispersed anterior pituitary cells were transferred to Linbro (Flow Laboratories, Inc., Rockville, MD) 24-well culture plates, 4-8 $\times 10^{5}$ cells/well, in $2 \mathrm{ml}$ of complete medium (RPMI 1640, 2.5\% fetal calf serum, 7.5\% horse serum, gentamicin $100 \mu \mathrm{g} / \mathrm{ml}$, Gibco Laboratories, Grand Island Biological Co., Grand Island, NY). The 
TABLE II

Basal Serum GH Levels for the 10-yr Period before the Diagnosis of Acromegaly Was Established in a Patient with a Pancreatic Tumor Secreting a GRF

\begin{tabular}{cc}
\hline Year & GH \\
\hline & $n g / m l$ \\
1971 & 1 \\
1972 & 6 \\
1974 & 7 \\
1975 & 8 \\
1977 & 35 \\
1978 & 74 \\
1980 & 86 \\
\hline
\end{tabular}

cells were allowed $3-4 \mathrm{~d}$ to attach in a humidified $37^{\circ} \mathrm{C}$ atmosphere with $95 \%$ air and $5 \% \mathrm{CO}_{2}$ before an experiment was performed. Immediately before a study, the cells were washed four times with serum-free RPMI 1640 medium with gentamicin to remove serum and previously secreted hormone. The control or test substances were diluted in a final volume of $2.3 \mathrm{ml}$ of serum-free medium per well and 300 $\mu \mathrm{l}$ aliquots were removed at $4 \mathrm{~h}$ for RIA of rat anterior pituitary hormones.

Human tumor-containing medium. Immediately following removal of the pancreatic tumor the tissue was sectioned into smaller pieces of $\sim 1 \mathrm{~g}$ each. These were placed into sterile RPMI 1640 medium supplemented with $10 \%$ horse serum, $2.5 \%$ fetal calf serum, $25 \mathrm{mM} \mathrm{HEPES}$, and antibiotics (hereafter called the "tumor medium"). Control medium contained the same constituents, but was never exposed to the tumor. These media were aliquoted and stored at $-80^{\circ} \mathrm{C}$ until immediately before the bioassay.

Extraction and chromatography of tumor. $2.5 \mathrm{~g}$ of the tumor as lyophilized, minced in a Polytron apparatus (Brinkmann Instruments, Inc., Westbury, NY) in $10 \mathrm{vol}$ acetone, maintained at $-20^{\circ} \mathrm{C}$ for $2 \mathrm{~d}$ and centrifuged. The acetone precipitate was extracted in hot $\left(>90^{\circ} \mathrm{C}\right) 10 \%$ formic acid containing $10 \mathrm{mM}$ EDTA and $0.5 \% \beta$-mercaptoethanol, for 2 min, dispersed with the Polytron, chilled, and centrifuged. The supernatant was defatted by three $\times 4 \mathrm{vol}$ of ether/petroleum ether $(1: 2)$ and applied to a $3.5 \times 120-\mathrm{cm}$ column of Sephadex G-50 (fine) and eluted with $3 \mathrm{~N}$ acetic acid, $0.5 \% \beta$-mercaptoethanol at a flow rate of $20 \mathrm{ml} / \mathrm{h}$. Fractions $(9.4 \mathrm{ml})$ of eluate were collected, assayed for peptide content by the Bio-Rad protein assay (Bio-Rad Laboratories, Richmond, CA) (17), lyophilized, and bioassayed in pools for their ability to stimulate immunoreactive GH secretion by rat anterior pituitary primary cultures as described by Vale et al. (16).

\section{RESULTS}

\section{Hormonal evaluation}

$\mathrm{GH}$ concentrations were measured retrospectively in basal serum samples that had been stored at $-20^{\circ} \mathrm{C}$ for up to $10 \mathrm{yr}$ (Table II). GH levels were clearly elevated for $>4$ yr before the diagnosis of acromegaly. In Table III the results of other endocrine testing before, following pituitary microsurgery, during bromocriptine therapy, and after removal of a pancreatic

TABLE III

Hormonal Data before and after Pituitary Microsurgery (TSS), during Bromocriptine Therapy and after Removal of Pancreatic GRF-secreting Tumor

\begin{tabular}{|c|c|c|c|c|}
\hline & $\begin{array}{l}\text { Before } \\
\text { TSS }\end{array}$ & $\begin{array}{c}7 \text { wk after } \\
\text { TSS }\end{array}$ & $\begin{array}{c}17 \mathrm{wk} \text { of } \\
\text { bromocriptine } 2.5 \mathrm{mg} \\
\text { q.i.d. }\end{array}$ & $\begin{array}{l}17 \mathrm{wk} \text { after removal } \\
\text { of pancreatic tumor }\end{array}$ \\
\hline \multicolumn{5}{|l|}{ Serum $\mathrm{GH}, n g / m l$} \\
\hline Basal & 151 & 19 & 67 & 7 \\
\hline Maximum after TRH & 600 & 93 & 662 & 7 \\
\hline \multicolumn{5}{|l|}{ Serum prolactin, $n g / m l$} \\
\hline Basal & 88 & 55 & 3 & 22 \\
\hline Maximum after TRH & 101 & 53 & 9 & 37 \\
\hline \multicolumn{5}{|l|}{ Serum TSH, $\mu U / m l$} \\
\hline Basal & 6 & 3 & $5^{\circ}$ & 2.5 \\
\hline Maximum after TRH & 24 & 6 & $31^{\circ}$ & 3.3 \\
\hline \multicolumn{5}{|l|}{ Plasma cortisol, $\mu g / d l$} \\
\hline Basal & & 9 & & \\
\hline Maximum after hypoglycemia & & 15 & & \\
\hline Serum thyroxine, $\mu g / d l$ & $7 \downarrow$ & $11 \S$ & $8 \S$ & $13 \S$ \\
\hline
\end{tabular}

- 4 wk on bromocriptine therapy.

t On replacement therapy with thyroid extract 2 grains daily.

$\S$ On replacement therapy with Synthroid $0.15 \mathrm{mg}$ q.d.

Normal ranges are given in text. 


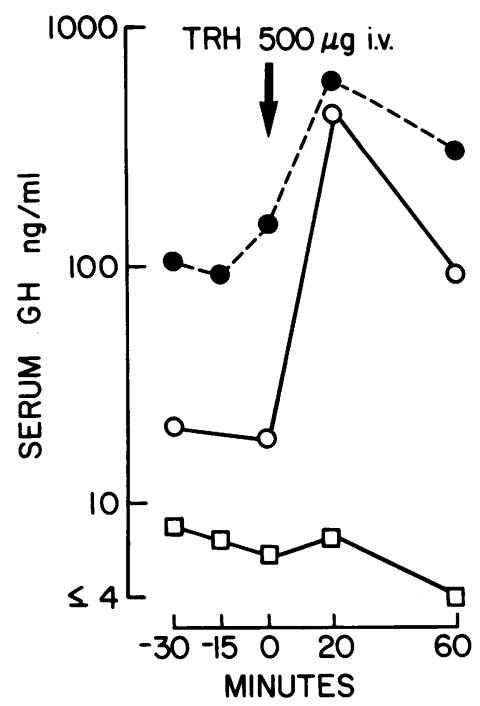

Figure 1 Serum GH concentration following $500 \mu \mathrm{g}$ TRH administered intravenously at $0 \mathrm{~min}$. Note the logarithmic scale. The test was performed before pituitary surgery $(0), 7 \mathrm{wk}$ after pituitary surgery $(0)$, and $17 \mathrm{wk}$ after removal of GRF-secreting pancreatic tumor ( $\square$ ). The rise of GH in response to TRH was observed before and after pituitary surgery. However, after removal of the GRF-secreting tumor basal GH levels were lowered to $<10 \mathrm{ng} / \mathrm{ml}$ and the paradoxical increase of GH to TRH was abolished. tumor are summarized. Basal serum prolactin levels were elevated $(88 \pm 3 \mathrm{ng} / \mathrm{ml} ; n=10$, mean $\pm \mathrm{SEM})$.

TRH, $500 \mu$ i.v., stimulated GH (Fig. 1) and prolactin release. An intravenous infusion of dopamine ( $4 \mu \mathrm{g} / \mathrm{kg}$ per $\mathrm{min}$ ) lowered serum $\mathrm{GH}$ by $43 \%$ and serum prolactin by $90 \%$. Following cessation of the infusion there was a rebound rise in the concentrations of both hormones (Fig. 2).

Serum GH decreased from $95 \pm 9.4 \mathrm{ng} / \mathrm{ml}$ preoperatively to $14 \mathrm{ng} / \mathrm{ml}$ at 6 and $12 \mathrm{~h}$ after transsphenoidal surgery, but rose to 35,51 , and $>70 \mathrm{ng} / \mathrm{ml}$ at 25,45 , and $72 \mathrm{~h}$ postoperatively and remained elevated. At 7 wk postoperatively the serum GH and somatomedin $\mathrm{C}$ levels remained elevated (Table $\mathrm{I}$ ). The patient was treated with bromocriptine ( $2.5 \mathrm{mg}$ q.i.d.) and the $\mathrm{GH}$ levels through the day $(n=10$, mean \pm SEM) before, at 7 and $17 \mathrm{wk}$ during, and $2 \mathrm{wk}$ after withdrawal were $77 \pm 8.4,56 \pm 3.3,71 \pm 8.4$, and $62 \pm 10.7 \mathrm{ng} / \mathrm{ml}$, respectively, and the serum prolactin concentrations were $32 \pm 1,2 \pm 0.3,3 \pm 0.4$, and $21 \pm 1.3 \mathrm{ng} / \mathrm{ml}$. Thus, bromocriptine suppressed the serum prolactin, but not the GH concentrations. Serum somatomedin C concentrations were unchanged (Table $\mathrm{I}$ ). The paradoxical GH stimulation to glucose and TRH persisted (Tables I and III and Fig. 1).

Following removal of the pancreatic tumor, serum
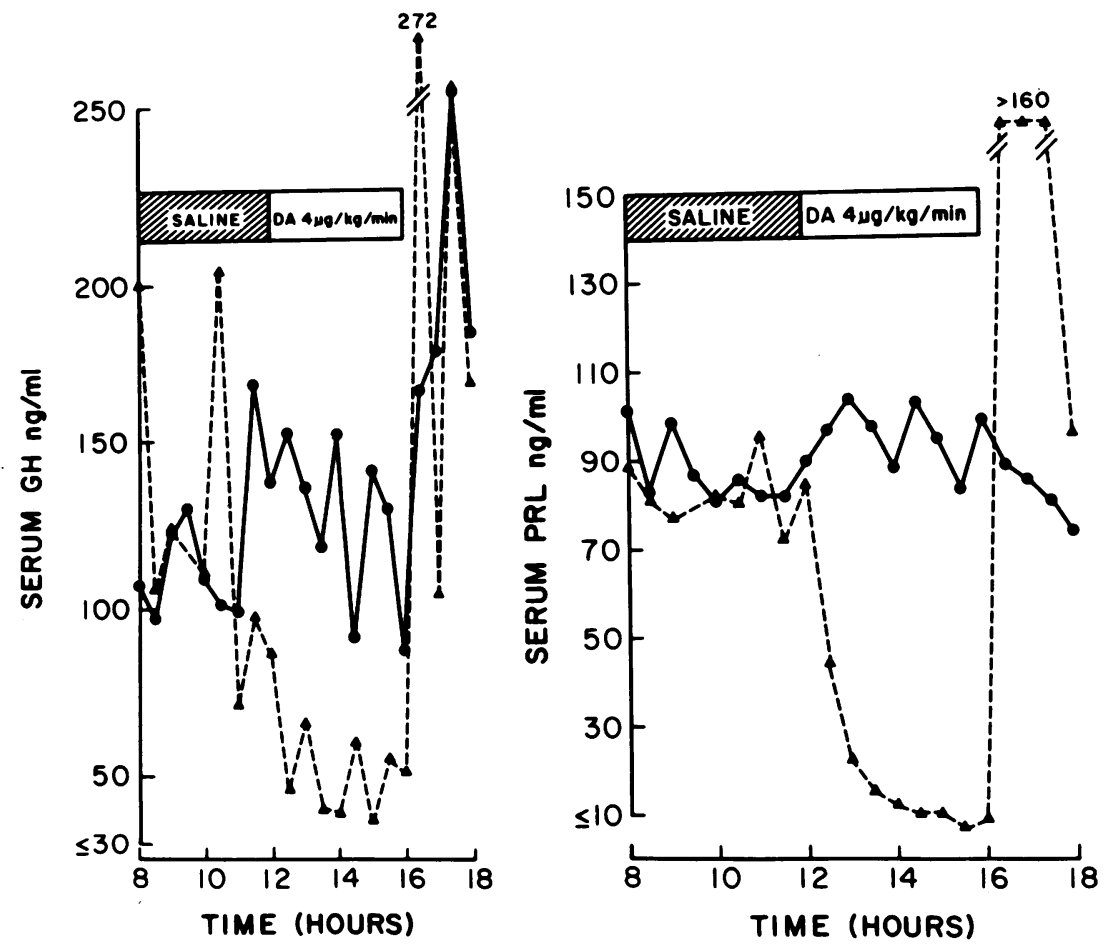

FIGURE 2 Serum GH (left) and prolactin (right) concentrations in a patient with somatotroph hyperplasia and acromegaly during an 8-h control infusion ( () and during a 4-h control infusion followed by a 4 -h dopamine infusion $(4 \mu \mathrm{g} / \mathrm{kg}$ per $\mathrm{min} ; \Delta)$. Note the suppression of prolactin and $\mathrm{GH}$ by dopamine and the rebound rise following its withdrawal. 
GH decreased over $2 \mathrm{~h}$ from 70 to $3 \mathrm{ng} / \mathrm{ml}$, although there was little change in serum prolactin (Fig. 3). 6 and $17 \mathrm{wk}$ postoperatively the serum somatomedin $\mathrm{C}$ level fell from a preoperative level of $8.6 \mathrm{U} / \mathrm{ml}$ to 1.2 $\mathrm{U} / \mathrm{ml}$ and $0.8 \mathrm{U} / \mathrm{ml}$, respectively. Similarly, $\mathrm{GH}$ concentrations throughout the day (mean $\pm \mathrm{SEM}, n=10$ ) decreased from $62 \pm 10.7 \mathrm{ng} / \mathrm{ml}$ to $4 \pm 0.3 \mathrm{ng} / \mathrm{ml}$ and $6 \pm 0.8 \mathrm{ng} / \mathrm{ml}$ at 6 and $17 \mathrm{wk}$ postoperatively. The GH response to glucose remained abnormal up to $17 \mathrm{wk}$ postoperatively, since the serum GH concentration did not suppress to $<2 \mathrm{ng} / \mathrm{ml}$ (Table I). However, during a 4-h dopamine infusion the paradoxical suppression of $\mathrm{GH}$ was absent, and there was a rise of $\mathrm{GH}$ from 3 to $10 \mathrm{ng} / \mathrm{ml}$ at $30 \mathrm{~min}$ after the commencement of the infusion (Fig. 4), and the paradoxical stimulations of GH to glucose and TRH (Fig. 1) were also absent (Tables I and III).

\section{Light microscopic, immunocytologic, and electron microscopic studies}

Morphologic features of the pituitary. By light microscopy, no tumor was identified. The adenohypophysis was composed predominantly of well-differentiated, densely granulated acidophilic cells arranged in large nests (Fig. 5a) that contained GH in their cytoplasm, as demonstrated by the immunoperoxidase technique (Fig. 5b). Many prolactin cells (Fig. 5c) and a few PAS-positive cells were randomly intermingled with the somatotrophs. Gonadotrophs were sparse and inconspicuous. No pleomorphism was noted nor were mitotic figures seen. The individual acini surrounded by reticulin fibers were larger than in the normal ad-

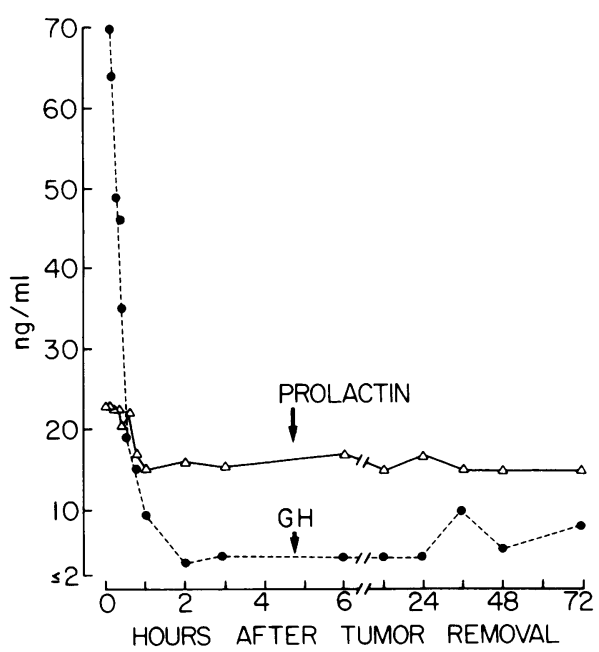

Figure 3 Serum GH and prolactin levels during and after removal of pancreatic tumor secreting GRF. Note the rapid fall of $\mathrm{GH}$ levels with no fall of prolactin levels following removal of the tumor.

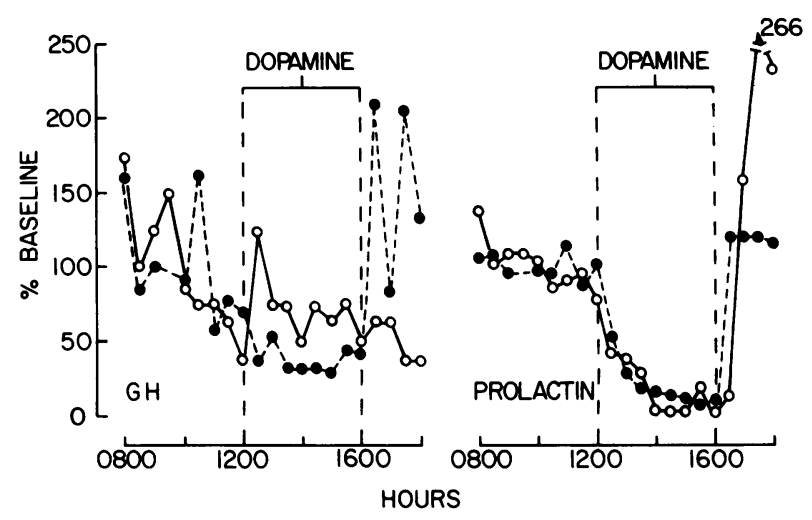

Figure 4 Serum GH (left) and serum prolactin (right) in a patient with somatotroph hyperplasia during a 4-h control infusion followed by a 4 -h dopamine infusion $(4 \mu \mathrm{g} / \mathrm{kg}$ per $\mathrm{min}$ ). The results are expressed as a percentage of base line. The base line is the mean of samples withdrawn during a 4-h control infusion. One study was performed before pituitary surgery when the mean serum GH ( \pm SEM) was $124 \pm 17 \mathrm{ng} / \mathrm{ml}$, and serum prolactin $83 \pm 2 \mathrm{ng} / \mathrm{ml}$ (these data are also shown in Fig. 2) (๑). The other study was performed $17 \mathrm{wk}$ after resection of pancreatic GRF-secreting tumor (O). Note suppression of GH by dopamine infusion, and rebound after its withdrawal before pituitary surgery. After pancreatic surgery, instead of a fall in $\mathrm{GH}$ values, there was an acute rise of $\mathrm{GH}$ following initiation of the dopamine infusion and no rebound following its cessation. In both studies serum prolactin concentrations fell during dopamine infusion and a rebound rise was observed following withdrawal of dopamine (right).

enohypophysis. No circumscribed mass, pseudocapsule formation, compressed areas nor condensation of reticulin fibers were identified. The reticulin network was preserved (Fig. 6). In some areas, the reticulin fibers were irregular or unusually well developed.

By electron microscopy, the overwhelming majority of cells were densely granulated somatotrophs. The nuclei were spherical or oval and contained prominent nucleoli. In the cytoplasm, the rough-surfaced endoplasmic reticulum (RER) membranes were moderately developed and consisted of slightly dilated parallel stacks studded with ribosomes on the external aspects. The Golgi complexes were conspicuous with the presence of numerous forming granules in the säcculi. The mitochondria were rod shaped, possessed lamellar cristae and a moderately electron dense matrix. The secretory granules were numerous, spherical or slightly irregular, evenly electron dense, and measured 200$600 \mathrm{~nm}$ in diameter. No exocytoses were seen. Lysosomes were inconspicuous. The fine structural features of the somatotrophs, except for the striking prominence of Golgi complexes, were similar to those seen in nontumorous adenohypophysis. Lactotrophs and a few corticotrophs, gonadotrophs, and thyrotrophs were interspersed among the GH cells. The gonadotrophs 

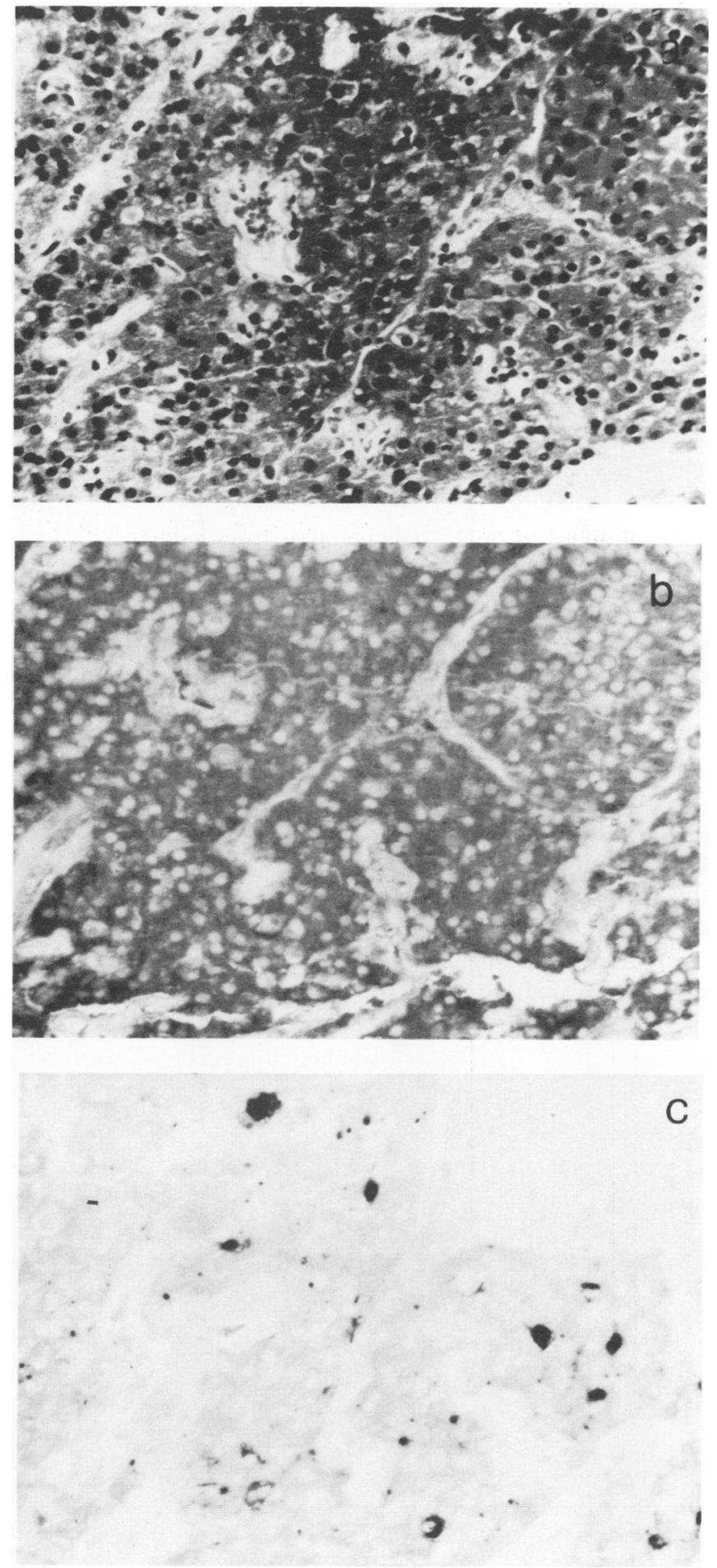

Figure 5 (a) Portion of adenohypophysis showing hyperplasia of acidophilic cells. Hematoxylin-phloxin-saffron stain. Original magnification $\times 250$. (b) The same area as shown in Fig. 5a and $5 \mathrm{c}$. The acidophilic cells exhibit well-defined staining for GH. Immunoperoxidase technique for GH. Original magnification $\times 250$. (c) The same area as shown in Fig. 5a and 5b. Scattered cells with prolactin immunostaining are apparent among the somatotrophs. Immunoperoxidase technique for prolactin. Original magnification $\times 250$. 


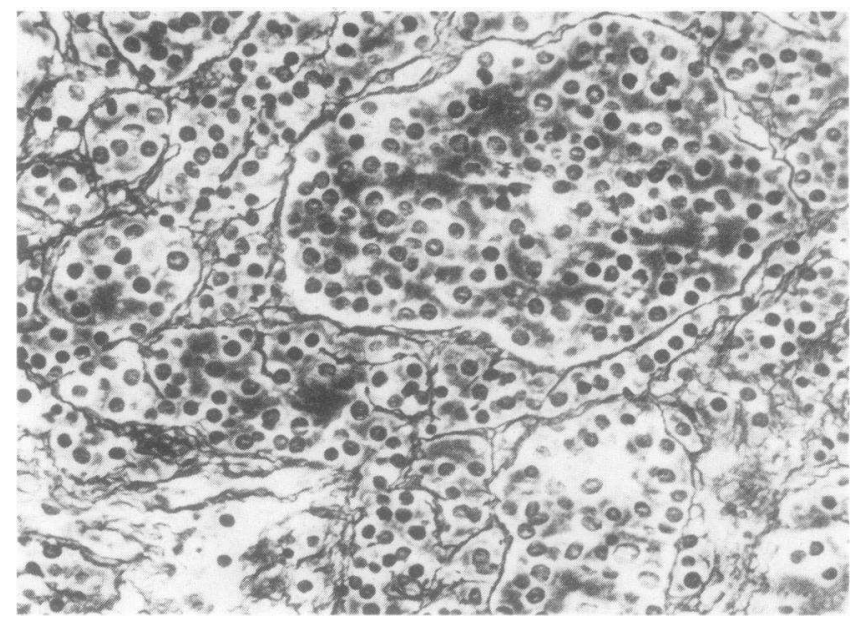

FIGURE 6 The reticulin network in adenohypophysis from patient with somatotroph hyperplasia is preserved but irregular. Gordon-Sweet technique. Original magnification $\times 250$.

were inconspicuous and failed to show ultrastructural signs of stimulation. No tumor was identified. These features are consistent with the diagnosis of somatotroph hyperplasia.

Morphologic features of the pancreatic tumor. The pancreatic tumor weighed $55 \mathrm{~g}$ and measured 5 $\mathrm{cm}^{3}$. The cut surface revealed a densely calcified capsule and areas of hemorrhage. The tumor was sharply demarcated and was surrounded by a thick fibrous capsule trapping a few small groups of islet cells. The tumor cells were arranged in smaller nests and formed glandular structures. Pleomorphism was slight; mitotic figures were very rare. A few PAS- and lead hema- toxylin-positive granules could be detected in the cytoplasm of some tumor cells. The Grimelius technique yielded inconclusive results for argyrophil granules. The immunoperoxidase method revealed strong cytoplasmic positivity for neuron-specific enolase, supporting the islet cell origin of the tumor (18). Immunostaining was negative for gastrin, insulin, glucagon, ACTH 1-39, calcitonin, GH and prolactin, and was inconclusive for somatostatin.

By electron microscopy, the tumor was composed of elongated, closely apposed cells with oval or irregular nuclei and prominent nucleoli (Fig. 7). The cytoplasm was well developed and contained many RER

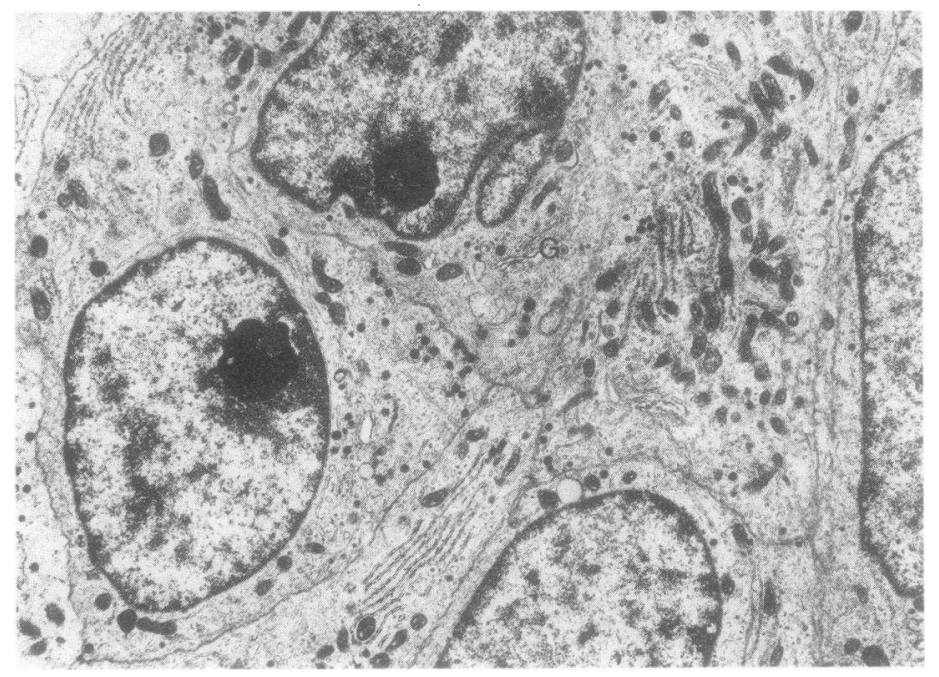

Figure 7 Electron micrograph of tumor cells showing prominent Golgi complexes (G), endoplasmic reticulum membranes, secretory granules, and mitochondria. Original magnification $\times 12,800$. 
profiles which, in some cells, formed fingerprint configurations (Nebenkerns). In some cells, the RER was unevenly dilated. The Golgi complexes were prominent. Some Golgi sacculi showed cystic dilatation, while others were flattened and contained a few immature secretory granules. The mitochondria were numerous, oval, or rod shaped with tubular cristae and electron dense matrix. The secretory granules varied widely in number and slightly in electron density from cell to cell; they measured $100-250 \mathrm{~nm}$ in diameter, the majority being $\sim 150 \mathrm{~nm}$. Lysosomes were inconspicuous. Between adjacent cells, desmosomal attachments were noted. In some areas, regressive changes, representing degeneration and necrosis of cells, were apparent. Focal calcification was seen in cell debris and extracellular spaces.

In summary, this tumor appeared to be of endocrine nature and to have arisen from the pancreatic islet cells. The morphologic features of the tumor cells differed from those of nontumorous islet cells. Hence, the cell type constituting the tumor could not be defined.

\section{GRF activity in the tumor medium}

The medium that held the human pancreatic tumor after surgery contained substance(s) that stimulated the release of rat GH from primary cultures of rat anterior pituitary cells (Table IV). By $4 \mathrm{~h}$, a 1:10 dilution of the tumor medium had stimulated rat GH release sevenfold over that of cells exposed to the control medium. By contrast, there was no apparent effect on prolactin release by the tumor medium at $4 \mathrm{~h}$.

\section{Chromatography and biological activity of extract of pancreatic tumor}

Sephadex G-50 chromatography of the tumor extract was performed. GH releasing activity was detected in fractions 47-54 (Fig. 8) corresponding to $K_{D}$ values of $0.27-0.39$. The extraction and chromatography of rat hypothalamic fragments by similar methods has resulted, in the detection of GH-releasing ac-

TABLE IV

Effect of a 1:10 Dilution of Human Tumor or Control Medium on Cumulative Rat GH and Prolactin Release at $4 h^{\circ}$

\begin{tabular}{lccc}
\hline \multicolumn{1}{c}{ Control } & Tumor & $P$ \\
\hline $\begin{array}{l}\text { Rat GH release, } n g / \text { well } \\
1,230 \pm 52(6)\end{array}$ & $8,630 \pm 505(3)$ & 0.01 \\
$\begin{array}{l}\text { Rat prolactin release, } n g / \text { well } \\
106 \pm 22(3)\end{array}$ & $118 \pm 6$ & (3) & NS \\
\hline
\end{tabular}

- Mean \pm SEM $(n)$ : two-tailed Student's $t$ test. tivity at comparable $K_{\mathrm{D}}$ values. ${ }^{2}$ The potency (active at $<10 \mathrm{ng} / \mathrm{ml}$ ) of this partially purified tumor fraction and its behavior on gel filtration similar to that of a rat hypothalamic $\mathrm{GH}$-releasing fraction are consistent with the tumor containing a GRF.

\section{DISCUSSION}

Acromegaly is usually caused by a well-defined microor macroadenoma composed of densely or sparsely granulated somatotrophs arising in the adenohypophysis (19-21). Occasionally, however, a tumor cannot be found and GH excess is associated with normal pituitary histology (22) or with diffuse somatotroph hyperplasia (23-25). Although the distinction between adenoma and hyperplasia may be difficult in some cases, characteristic morphologic features may permit a precise diagnosis. Adenomas usually are well demarcated and consist of one cell type that differs from surrounding nontumorous adenohypophysial cells. Although adenomas are not encapsulated, they possess a pseudocapsule of condensed reticulin fibers that separate the tumor from adjacent, compressed normal pituitary tissue. Adenomas show a strikingly irregular arrangement or loss of the reticulin fiber network.

In 125 consecutive cases of acromegaly (examined by one of us [K.K.]), the tissue obtained at surgery contained a pituitary adenoma. In only this case was somatotroph hyperplasia found. We submit that the diagnosis of somatotroph hyperplasia is justified in this patient, because no circumscribed mass was evident; the somatotrophs were very numerous but were intermingled with other adenohypophysial cell types; neither a pseudocapsule nor compression of surrounding tissue was present; and the reticulin network was preserved.

Both of the recently documented cases of somatotroph hyperplasia have been due to extrapituitary tumors, which have been shown, either definitively or presumptively, to secrete a GRF $(8,10)$. Other cases of ectopic GRF secretion have been associated with either presumed or proven somatotroph adenoma. These GRF-secreting tumors have included islet cell tumors of the pancreas and carcinoid tumors (1-10).

On the basis of the continued signs, symptoms, and biochemical evidence of acromegaly following transsphenoidal surgery, along with the pituitary histology, we made a search for a GRF-secreting tumor. The location and histology of the pancreatic tumor suggested that it originated in the islet cells and could be classified as neuroendocrine in origin, based on

\footnotetext{
${ }^{2}$ Vale, W., J. Vaughan, and J. Rivier. Manuscipt in preparation.
} 


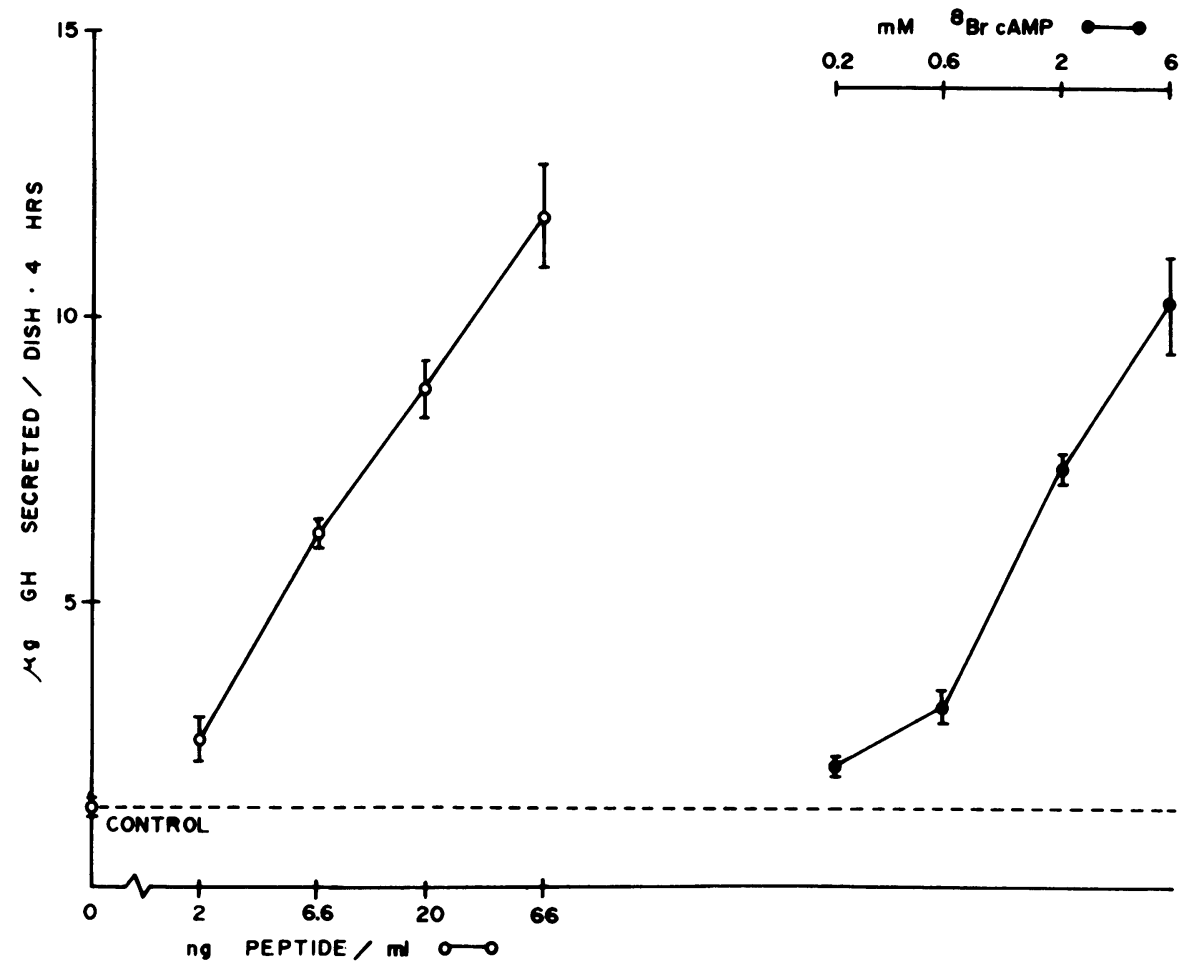

Figure 8 Effects of ${ }^{8} \mathrm{Br} 3^{\prime} 5^{\prime}$ cyclic AMP (๑) and fractions 47-54 (O) from Sephadex G-50 chromatography of tumor extract on $\mathrm{GH}$ secretion by $4-\mathrm{d}$ primary cultures of rat anterior pituitary cells. Peptide content of fractions 47-54 was based upon Bio-Rad protein assay.

the presence of neuron-specific enolase immunostaining (18).

That this tumor secreted a GRF was confirmed by reduction of GH levels within minutes of tumor removal, with persistently normal GH levels postoperatively; the finding of GRF-like activity in the extract of the tumor; and the in vitro secretion of a product with GRF-like activity by tumor cells in culture (26). Because no RIA for GRF is currently available, we were unable to demonstrate an arteriovenous gradient for GRF across the tumor bed. Furthermore, the GH levels measured on the stored samples suggested that our patient had GH hypersecretion for at least $4 \mathrm{yr}$ before the diagnosis of acromegaly was established.

GH secretion is under dual hypothalamic control consisting of tonic inhibition and stimulation by somatostatin and GRF, respectively. Somatostatin was described in 1968 (27) and its structure reported in 1973 (28). In 1960 Reichlin (29-30) first proposed the existence of a GRF in the hypothalamus. Deuben and Meites (31) presented evidence for a GRF in rat hypothalamic extracts in 1964. Since then the isolation of GRF has been elusive, although several partially purified hypothalamic peptides have been reported (32-36). Occasionally carcinoid or pancreatic islet cell tumors have been implicated in the secretion of a GRF (5-10). Frohman et al. $(37,38)$ reported the partial characterization of GRF activity from a bronchial carcinoid tumor and a pancreatic islet cell tumor, as well as the screening of a number of other tumors for GRF activity. They showed that other potential secretory products from these tumors could not stimulate $\mathrm{GH}$ release from cultured rat pituitary cells. The GRF moiety in both tumors was a peptide, as demonstrated by peptidase-mediated degradation of biological activity. By gel filtration chromatographic criteria the GRF from our patient's tumor eluted in the same position as rat hypothalamic GRF activity.

Significant GRF activity was demonstrated with 40 ng of the partially purified GRF from Frohman's carcinoid tumor $(37,38)$, while our GRF extract demonstrated a dose-related increase in activity from 2 to $66 \mathrm{ng}$ peptide $/ \mathrm{ml}$ incubation medium, which suggests that it is active in the nanomolar range (Fig. 8). We have shown that the medium containing GRF not only stimulated GH secretion by the pituitary cells in culture, but also led to the accumulation of cyclic AMP within the cells in a dose-related fashion (15). Both the GH stimulation and accumulation of cyclic AMP are inhibited by somatostatin (15). The dose-response 
curves of the extract of GRF and 8-bromo-cyclic AMP on $\mathrm{GH}$ release from primary cultures of rat pituitary cells are parallel. This observation together with stimulation of cyclic AMP accumulation in the pituitary by GRF support the contention that a second messenger for GRF may be cyclic AMP $(39,40)$ (Fig. 8).

Hyperprolactinemia was present with somatotroph hyperplasia and no demonstrable pituitary tumor. The cause of the hyperprolactinemia is unknown; it is unlikely to have been due to an oral contraceptive preparation or to hypothyroidism (the patient was on thyroid replacement with normal serum thyroxine concentrations). Since there was no decrease in prolactin compared with GH levels after the removal of the pancreatic tumor, it is unlikely that this GRF is also a prolactin-releasing factor.

The paradoxical stimulation of GH secretion by glucose and TRH and the suppression of $\mathrm{GH}$ by dopamine are considered to be characteristic responses of a majority of tumors in acromegalic patients. It has been suggested that these responses to TRH and dopamine represent dedifferentiation of the somatotrophs (4144), but this may not be correct. This patient offered us the opportunity to evaluate the importance of stimulation of the pituitary by GRF on these responses. These abnormal responses disappeared when the source of GRF was removed; thus, they are probably due to either the GRF/somatostatin input or the primary increased GH secretion rate, rather than to cellular dedifferentiation (not apparent on histopathology).

After removal of the GRF-secreting pancreatic tumor, GH levels fell from 70 to $3 \mathrm{ng} / \mathrm{ml}$. However, at 6 and 17 wk postoperatively, GH levels during OGTT did not suppress to $<2 \mathrm{ng} / \mathrm{ml}$. In spite of the failure to suppress, serum somatomedin levels fell progressively to $1.2 \mathrm{U} / \mathrm{ml}$ and $0.8 \mathrm{U} / \mathrm{ml}$ at 6 and $17 \mathrm{wk}$, respectively. The continued hypersecretion of GH may reflect a resetting of the hypothalamus due to prolonged feedback of somatomedin C and/or GRF. Although at first consideration, suppression of $\mathrm{GH}$ secretion might be anticipated, the dual control of $\mathrm{GH}$ secretion by GRF and somatostatin may result in unpredictable changes in their release and thus of $\mathrm{GH}$. Therefore, a considerable time may be needed for the normal control to be restored, in the same manner as the hypothalamic-pituitary-adrenal axis often requires many months to recover following removal of an ACTH-secreting tumor (45).

Willemse (46) reported acromegaly in a young woman with Turner's syndrome who had been treated with estrogens to promote linear growth. At surgery a pituitary tumor was removed. In our patient we believe that acromegaly and Turner's syndrome are coincidental. In this patient GH hypersecretion was documented together with extremely high somatomedin
C levels and this was associated with the acromegalic features of increased hand and shoe size and changes in facial features. These biochemical and clinical signs regressed when the pancreatic GRF-secreting tumor was removed. Thus, at least the soft tissues are able to respond to pathologically elevated levels of $\mathrm{GH}$ and somatomedin C.

In our patient the pituitary enlargement was due to the somatotroph hyperplasia. Thus, the radiological evaluation was not helpful in distinguishing hyperplasia from pituitary tumor. None of the available tests for $\mathrm{GH}$ secretion is specific for a $\mathrm{GH}$-secreting pituitary adenoma.

Our experience with this patient highlights the importance of proper pituitary histology to distinguish hyperplasia from adenoma. Ideally, this condition should be diagnosed before pituitary surgery. However, none of the radiological or dynamic endocrine tests performed currently are able to distinguish the acromegalic patient with a pituitary adenoma from that with a GRF-secreting tumor. If the incidence of GRF-secreting tumors is $<1 \%$ of patients with acromegaly, routine body CT scans to diagnose these tumors may not be considered cost effective, although intellectually satisfying. Ultimately, the characterization of GRF and the development of a RIA for GRF may enable these patients to be diagnosed by simple blood tests. In such patients, a thorough search to identify any ectopic GRF-secreting tumor is mandatory.

Note added in proof. The GRF extracted and purified from this pancreatic tumor has been sequenced by Drs. Vale, Rivier, and Spiess at the Peptide Biology Laboratory of the Salk Institute (Spiess, J., J. Rivier, M. O. Thorner, and W. Vale. Primary structure of a growth hormone-releasing factor from a human pancreatic islet tumor. Biochemistry. In press). It is suggested to be a 40 -amino acid peptide. Several synthetic replicates of varying length from the $\mathrm{N}$-terminal were found to have full biological potency in vivo and in vitro. An unexpected finding was that there is a close structural homology of GRF with peptides of the glucagon-secretin family, particularly the intestinal peptide porcine $\mathrm{PHI}$ (the peptide [P] having $\mathrm{NH}_{2}$-terminal histidine [H], a $\mathrm{COOH}$ terminal isoleucine [I] amide. (Tatemoto, K., and V. Mutt. 1981. Isolation and characterization of the intestinal peptide porcine PHI [PHI-27], a new member of the glucagon-secretin family. Proc. Natl. Acad. Sci. USA. 78: 6603-6607).

\section{ACKNOWLEDGMENTS}

The authors wish to thank the staff of the Clinical Research Center for patient care and their technical help; the Pituitary Hormone Distribution Program for RIA reagents for measurement of human $\mathrm{GH}, \mathrm{LH}$, and $\mathrm{FSH}$, and rat prolactin and GH; Ms. Rebecca Weaver, Mrs. E. Elizabeth Taylor, and Mrs. Catherine Harcus for technical assistance; Mrs. Donna Harris for her assistance in the preparation of the manuscript; and Ms. Bertha Khoury for clinical assistance. Many thanks to Mrs. Nancy Ryan for her contribution in the immunocytologic work and to Dr. P. J. Marangos of the 
National Institute of Health, Bethesda, MD for kindly supplying the neuron-specific enolase antiserum.

These studies were supported, in part, by U. S. Public Health Service general clinical research grant RR-847; diabetes research and training grant $\mathrm{P} 60$ AM 22125; RO1 HD13197 (MOT); RCDA 1 K04N500601 (MJC); RCDA 1-K04 AM 00153 (ADR); and R01 AM-2674l (WV).

\section{REFERENCES}

1. Southern, A. L. 1960. Functioning metastatic bronchial carcinoid with elevated levels of serum and cerebrospinal fluid serotonin and pituitary adenoma. J. Clin. Endocrinol. Metab. 20: 298-305.

2. Weiss, L., and M. Ingram. 1961. Adenomatoid bronchial tumors: a consideration of the carcinoid tumors and the salivary tumors of the bronchial tree. Cancer. 14: 161178.

3. Buse, J., M. G. Buse, and W. J. Roberts. 1961. Eosinophilic adenoma of the pituitary and carcinoid tumors of the rectosigmoid area. J. Clin. Endocrinol. Metab. 21: 735-738.

4. Dabek, J. T. 1974. Bronchial carcinoid tumor with acromegaly in two patients. J. Clin. Endocrinol. Metab. 38: 329-333.

5. Sonksen, P. H., A. B. Ayrrs, M. Braimbridge, B. Corrin, D. R. Davies, G. M. Jeremiah, S. W. Oaten, C. Lowy, and T. E. T. West. 1976. Acromegaly caused by bronchial carcinoid tumors. Clin. Endocrinol. 5: 503-513.

6. Ballard, H. S., B. Frame, and R. J. Hartsock. 1964. Familial multiple endocrine adenoma-peptic ulcer complex. Medicine (Baltimore). 43: 481-516.

7. Caplan, R. H., L. Koob, R. M. Avellera, A. S. Pagliara, K. Kovacs, and R. V. Randall. 1978. Cure of acromegaly by operative removal of an islet cell tumor of the pancreas. Am. J. Med. 64: 874-882.

8. Shalet, S. M., C. G. Beardwell, I. A. MacFarlane, M. L. Ellison, C. M. Norman, L. H. Rees, and M. Hughes. 1979. Acromegaly due to production of a growth hormonereleasing factor by a bronchial carcinoid tumor. Clin. Endocrinol. 10: 61-67.

9. wz Zafar, M. S., R. C. Mellinger, G. Fine, M. Szabo, and L. A. Frohman. 1979. Acromegaly associated with a bronchial carcinoid tumor: evidence for ectopic production of growth hormone-releasing activity. J. Clin. Endocrinol. Metab. 48: 66-71.

10. Leveston, S. A., D. W. McKeel, P. J. Buckley, K. Deschryver, M. H. Greider, B. M. Jaffe, and W. H. Daughaday. 1981. Acromegaly and Cushing's syndrome associated with foregut carcinoid tumor. J. Clin. Endocrinol. Metab. 53: 682-689.

11. Di Chiro, G., and K. B. Nelson. 1962. The volume of the sella turcica. Am. J. Roentgenol. 87: 989-1008.

12. Thorner, M. O., W. H. Martin, A. D. Rogol, J. L. Morris, R. L. Perryman, B. P. Conway, S. S. Howards, M. G. Wolfman, and R. M. MacLeod. 1980. Rapid regression of pituitary prolactinomas during bromocriptine treatment. J. Clin. Endocrinol. Metab. 51: 438-445.

13. Furlanetto, R. W., L. E. Underwood, J. J. Van Wyk, and A. J. D'Ercole. 1977. Estimation of somatomedin C levels in normals and patients with pituitary disease by radioimmunoassay. J. Clin. Invest. 60: 648-657.

14. Kovacs, K., E. Horvath, and N. Ryan. 1981. Immunocytology of the human pituitary. In Diagnostic Immunocytochemistry. R. A. DeLellis, editor. Masson Publishing USA, Inc., New York. 17-35.

15. Cronin, M. J., A. D. Rogol, L. G. Dabney, and M. O.
Thorner. 1982. Selective growth hormone and cyclic AMP stimulating activity is present in a human pancreatic islet cell tumor. J. Clin. Endocrinol. Metab. 55: 381-383.

16. Vale, W., G. Grant, M. Amoss, R. Blackwell, and R. Guillemin. 1972. Culture of enzymatically dispersed anterior pituitary cells: functional validation of a method. Endocrinology. 91: 562-572.

17. Bradford, M. M. 1976. A rapid and sensitive method for the quantitation of microgram quantities of protein utilizing the principle of protein-dye binding. Anal. Biochem. 72: 248-254.

18. Tapia, F. J., J. M. Polak, A. J. A. Barbosa, S. R. Bloom, P. J. Marangos, C. Dermody, and A. G. E. Pearse. 1981. Neuron-specific enolase is produced by neuroendocrine tumours. Lancet. 1: 808-811.

19. Kernohan, J. W., and G. P. Sayre. 1956. Tumors of the pituitary gland and infundibulum. In Atlas of Tumor Pathology. Section X, Fascicle 36. Armed Forces Institute of Pathology, Wash., DC. 1-81.

20. Kovacs, K., E. Horvath, and C. Ezrin. 1977. Pituitary adenomas. Pathol. Annu. 12: 341-382.

21. Arafah, B. U. M., J. S. Brodkey, B. Kaufman, M. Velasco, A. Manni, and O. H. Pearson. 1980. Transsphenoidal microsurgery in the treatment of acromegaly and gigantism. J. Clin. Endocrinol. Metab. 50: 578-585.

22. Feingold, K. R., I. D. Goldfine, and P. R. Weinstein. 1979. Acromegaly with normal growth-hormone levels and pituitary histology. Case report. J. Neurosurg. 50: 503-507.

23. Lewis, D. D. 1905. Hyperplasia of the chromophile cells of the hypophysis as the cause of acromegaly, with report of a case. Bull. Johns Hopkins Hosp. 16: 157-164.

24. Bailey, P., and L. M. Davidoff. 1925. Concerning the microscopic structure of the hypophysis cerebri in acromegaly (based on a study of tissues removed at operation from 35 patients). Am. J. Pathol. 1: 185-207.

25. Russfield, A. B., L. Reiner, and H. Klaus. 1956. The endocrine significance of hypophyseal tumors in man. Am. J. Pathol. 32: 1055-1075.

26. Cronin, M., A. Rogol, I. Login, D. Keefer, R. MacLeod, and $\mathrm{M}$. Thorner. 1982. Growth hormone-releasing factor in a human tumor. Fed. Proc. 41: 1488a.

27. Kruhlich, L., A. P. S. Dhariwal, and S. M. McCann. 1968. Stimulatory and inhibitory effects of purified hypothalamic extracts on growth hormone release from rat pituitary in vitro. Endocrinology. 83: 783-790.

28. Brazeau, P., W. Vale, R. Burgus, N. Ling, M. Butcher, J. Rivier, and R. Guillemin. 1973. Hypothalamic polypeptide that inhibits the secretion of immunoreactive growth hormone. Science (Wash., DC). 179: 77-79.

29. Reichlin, S. 1960. Growth and the hypothalamus. Endocrinology. 67: 760-773.

30. Reichlin, S. 1961. Growth hormone content of pituitaries from rats with hypothalamic lesions. Endocrinology. 69: 225-230.

31. Deuben, R. R., and J. Meites. 1964. Stimulation of pituitary growth hormone release by a hypothalamic extract in vitro. Endocrinology. 74: 408-414.

32. Frohman, L. A., J. W. Maran, and A. P. S. Dhariwal. 1971. Plasma growth hormone responses to intrapituitary injections of growth hormone-releasing factor (GRF) in the rat. Endocrinology. 88: 1483-1488.

33. Wilber, J. F., T. Nagel, and W. F. White. 1971. Hypothalamic growth hormone-releasing activity (GRA): characterization by the in vitro rat pituitary and radioimmunossay. Endocrinology. 89: 1419-1424. 
34. Johansson, K. N-G., B. L. Currie, and K. Folkers, 1974. Identification and purification of factor B-GHRH from hypothalami which release growth hormone. Biochem. Biophys. Res. Commun. 60: 610-615.

35. Takahara, J., A. Arimura, and A. V. Schally. 1975. Assessment of GH-releasing hormone activity in Sephadexseparated fractions of porcine hypothalamic extracts by hypophyseal portal vessel infusion in the rat. Acta Endocrinol. 78: 428-434.

36. Nair, R. M. G., C. DeVillier, M. Barnes, J. Antalis, and D. L. Wilbur. 1978. A bovine hypothalamic peptide possessing immunoreactive growth hormone-releasing activity. Endocrinology. 103: 112-120.

37. Frohman, L. A., M. Szabo; M. Berelowitz, and M. E. Stachura. 1980. Partial purification and characterisation of a peptide with growth hormone-releasing activity from extrapituitary tumors in patients with acromegaly. J. Clin. Invest. 65: 43-54.

38. Frohman, L. A., and M. Szabo. 1981. Ectopic production of growth hormone-releasing factor by carcinoid and pancreatic islet tumor associated with acromegaly. In Physiopathology of Endocrine Diseases and Mechanisms of Hormone Action. R. J. Soto, J. Blaquier, and A. de Nicola, editors. Alan R. Liss, Inc., New York. 259-271.

39. Peake, G. T. 1973. The role of cyclic nucleotides in the secretion of pituitary growth hormone. In Frontiers in Neuroendocrinology. W. F. Ganong and L. Martini, editors. Oxford University Press, London. 173-208.

40. Thorner, M. O., J. T. Hackett, F. Murad, and R. M. MacLeod. 1980. Calcium rather than cyclic AMP as the physiological intracellular regulator of prolactin release. Neuroendocrinology. 31: 390-402.

41. Hoyte, K. M., and J. B. Martin. 1975. Recovery from paradoxical growth hormone responses in acromegaly after transsphenoidal selective adenectomy. J. Clin. Endocrinol. Metab. 41: 656-695.

42. Muller, E. E., A. Liuzzi, D. Cocchi, A. E. Panerai, G. Oppizzi, V. Locatelli, P. Mantegazza, F. Silvestrini, and P. G. Chiodini. 1977. The role of dopaminergic receptors in regulation of growth hormone secretion. In Advances in Biochemical Psychopharmacology. E. Costa and G. L. Gessa, editors. Raven Press, New York. 16: 127138 .

43. Liuzzi, A., P. G. Chiodini, F. Silvestrini, R. Cozzi, G. Opizzi, L. Botalla, and G. Verde. 1979. Effects of neuroactive drugs on growth hormone and prolactin secretion in acromegaly. In Pituitary Microadenomas. G. Faglia, M. A. Giovanelli, and R. M. MacLeod, editors. Academic Press, Inc., London. 367-381.

44. Marcovitz, S., C. G. Goodyer, H. Guyda, R. J. Gardiner, and J. Hardy. 1982. Comparative study of human fetal, normal adult, and somatotropic adenoma pituitary function in tissue culture. J. Clin. Endocrinol. Metab. 54: 616.

45. Schall, A. M., J. S. Brodkey, B. Kaufman, and O. H. Pearson. 1978. Pituitary function after removal of pituitary microadenomas in Cushing's disease. J. Clin. Endocrinol. Metab. 47: 410-417.

46. Willemse, C. H. 1962. A patient suffering from Turner's syndrome and acromegaly. Acta Endocrinol. 39: 204212. 